\title{
Distribution of fish in seagrass, mangroves and coral reefs: life-stage dependent habitat use in Honduras
}

\author{
Jessica Jaxion-Harm ${ }^{1}$, James Saunders ${ }^{2}$ \& Martin R. Speight ${ }^{1}$ \\ 1. Department of Zoology, University of Oxford, South Parks Rd., OX1 3PS, UK; jessica.jaxion.harm@gmail.com, \\ martin.speight@zoo.ox.ac.uk \\ 2. Coral View Research Center, Utila, Honduras; jesaunders25@gmail.com
}

Received 14-IV-2011. Corrected 02-X-2011. Accepted 04-XI-2011.

\begin{abstract}
Many coral reef fish exhibit habitat partitioning throughout their lifetimes. Such patterns are evident in the Caribbean where research has been predominantly conducted in the Eastern region. This work addressed the paucity of data regarding Honduran reef fish distribution in three habitat types (seagrass, mangroves, and coral reefs), by surveying fish on the islands of Utila and Cayos Cochinos off the coast of Honduras (part of the Mesoamerican barrier reef). During July $2^{\text {nd }}$ - Aug 27th 2007 and June 22nd - Aug 17th, 2008, visual surveys (SCUBA and snorkel) were performed in belt transects in different areas: eleven coral reef, six seagrass beds, and six mangroves sites. Juvenile densities and total habitat surface area were used to calculate nursery value of seagrass and mangroves. A total of 113 fish species from 32 families were found during underwater surveys. Multi-dimensional analyses revealed distinct clusters of fish communities in each habitat type by separating fish associated with seagrass beds, mangroves, and coral reefs. Coral reefs showed the highest mean fish species richness and were dominated by adult fish, while juvenile fish characterized seagrass beds and mangrove sites. Habitat use differed widely at the fish species level. Scarus iseri (Striped Parrotfish), the most abundant fish in this study, were found in all three habitat types, while Lutjanus apodus (Schoolmaster Snapper) juveniles were located primarily in mangroves before migrating to coral reefs. Many species used seagrass beds and mangroves as nurseries; however, the nursery value could not be generalized at the family level. Furthermore, for some fish species, nursery value varied between islands and sites. Our results suggest that connectivity of seagrass, mangrove, and coral reef sites at a species and site levels, should be taken into consideration when implementing policy and conservation practices. Rev. Biol. Trop. 60 (2): 683-698. Epub 2012 June 01.
\end{abstract}

Key words: coral reef fish, connectivity, nursery, seagrass, mangroves, Honduras.

Shallow coastal areas of tropical latitudes include a mosaic of habitats. The term 'habitat' was defined by Beck et al. (2001) as "the area used by a species." However, migrant species may use the whole coastal zone. Therefore, in the present study, habitat is defined as environmentally uniform regions such as mangrove forests, seagrass beds, and coral reefs. While containing highly diverse fish and invertebrate assemblages, these tropical habitats are heavily impacted by anthropogenic influences (climate change, dredging, eutrophication) (Halpern et al. 2008). Specifically, 20\% of mangroves have been deforested worldwide since the 1980s, $29 \%$ of seagrass beds have been lost, and $35 \%$ of coral reefs are under threat of collapse (Wilkinson 2008, Anonymous 2007, Waycott et al. 2009). These habitats are vitally important to marine fish communities, and their loss may affect fisheries because many fish species found in these habitats are economically important.

Distribution patterns of fish may depend on behavioral responses to refuge availability provided by structural complexity (Cocheret de la Morinière et al. 2004, Pittman et al. 2004) and available resources such as food 
(Laegdsgaard \& Johnson 2001, Verweij et al. 2006), or they may be a result of predation and competition interactions (Laegdsgaard \& Johnson 2001, Almany 2004). Tropical coral reef fish utilize multiple habitat types during their life histories (Gratwicke et al. 2006, Nagelkerken et al. 2000a). Many species use seagrass and mangroves as juvenile nursery grounds before undergoing migration to reefs (Nakamura et al. 2008, Verweij et al. 2008). In this paper, ontogenetic migration refers to mono-directional migration; i.e. once fish migrate to their adult habitat, they do not return to their previous juvenile habitats. Ontogenetic migration suggests that younger, smaller fish may require different habitat resources to their adult counterparts. To determine the values of mangroves and seagrass beds in the present study, nursery function and effective juvenile habitat calculations were made. Habitats with nursery function (NF) should contribute greater than average abundances to adult populations per unit area (Beck et al. 2001). Effective juvenile habitat $(\mathrm{EJH})$ is defined as habitat that makes a greater than average total contribution to adult populations, and although it may not have high contributions per unit area, these habitats may be necessary to sustain populations (Dahlgren et al. 2006). In order to study the importance of nursery grounds, the present study categorized fish into three different life history strategies: habitat specialists (all life stages use a single habitat), habitat generalists (move freely between habitats), and ontogenetic shifters (habitat use is dependent on life stage) (Adams et al. 2006). They were also divided into juveniles versus adults. In the present study, ontogenetic shifters used nursery habitat (seagrass beds, mangroves) as juveniles, but were found primarily on reefs as adults; therefore these fish species were classified as nursery species.

In the Caribbean, most studies have quantified fish assemblages from the island nations of the Eastern region (Nagelkerken et al. 2000a, Layman et al. 2004, Gratwicke et al. 2006, Dorenbosch et al. 2007, Aguilar-Perera \& Appeldoorn 2008). The Mesoamerican
Barrier Reef System (MBRS: Yucatan Peninsula, Belize, Honduras) is the second largest barrier reef in the world and is located closer to continental Central America compared to the island nations of the Eastern Caribbean. Scientists have performed surveys to quantify MBRS fish assemblages in seagrass beds, mangrove, and coral reef habitats of Belize and Mexico (Mumby et al. 2004, Chittaro et al. 2005). However, studies of Honduran reefs are limited to Clifton \& Clifton (1998) who provided a comprehensive list of fish species found on the coral reefs of Honduran archipelago Cayos Cochinos, and Greenfield \& Johnson (1990a, 1990b) who performed multiple habitat surveys focusing on fish from the blennioid and cardinalfish families. Although Honduran reefs comprise more than $30 \%$ of the MBRS, fish use of shallow back reef habitat has never been studied. The Honduran islands of Utila and Cayos Cochinos were chosen because they are surrounded by a diverse array of coral reefs, mangroves, and seagrass beds, including a simple isolated mangrove lagoon, coral with adjacent seagrass beds, and a highly connected coral-seagrass-mangrove continuum.

The objectives of the present study in Honduras were to survey multiple habitats and to use the obtained data to answer the following questions: (1) Which fish species occupy a specific habitat? and are there any differences in fish species richness and overall abundance between seagrass beds, mangroves and corals? (2) Do juvenile fish of coral reefs use seagrass beds and mangroves as nursery grounds (NF and $\mathrm{EJH})$ ? And does life-stage habitat partitioning suggest habitat connectivity? (3) Do fish communities differ between habitat types?

\section{MATERIALS AND METHODS}

Study site: Cayos Cochinos (Cayos Mejor, Cayos Menor, and cays; 1556'3" - 15'58'49" $\mathrm{N}$ and $86^{\circ} 28^{\prime} 02^{\prime \prime}-86^{\circ} 31^{\prime} 24^{\prime \prime} \mathrm{W}$ ) and Utila (Southernmost of the Bay Islands, $16^{\circ} 03^{\prime} 47^{\prime \prime}$ - 1607'07" N and 86 $6^{\circ} 53^{\prime} 01^{\prime \prime}$ - 86 $6^{\circ} 59^{\prime} 41^{\prime \prime}$ W) are islands off the Caribbean coast of Honduras that are surrounded by seagrass 
beds (from now on seagrass) followed by coral reefs in slightly deeper waters (Fig. 1). Although percent hard coral on surveyed reefs was reasonably high $(\sim 18 \%)$, algae dominated the reefs $(\sim 40 \%)$. Cayos Cochinos supports a very small $(<250 \mathrm{~m})$ mangrove stand (fringing mangroves in an open system located adjacent to seagrass and coral reefs) on the Eastern side of Cayos Mejor. Mangroves dominate the interior of Utila and the coastline on its North side (mangrove stands). However, mangroves on Utila's South side are limited to two large lagoons (shallow, highly sedimentous bodies of water semi-separated from the open sea) and a few highly-fragmented stands of mangroves on the Southern coastline. Oyster Bed Lagoon is surrounded by $\sim 5.5 \mathrm{~km}$ of Rhizopora mangle (Red Mangroves), while its interior substrate is dominated by algal beds and silt. A $75 \mathrm{~m}$ wide channel connects Oyster Bed Lagoon to open seagrass and coral reef habitats of the Caribbean Sea. Mangrove trees reached an average height of $2 \mathrm{~m}$ with dense prop roots extending into water at a mean depth of $50 \mathrm{~cm}$. Seagrass species Thalassia testudinum (Turtle Grass) and Syringodium filiforme (Manatee Grass) dominated the beds with blade density $\sim 65$ blades per $\mathrm{cm}$ and blade height $\sim 25 \mathrm{~cm}$. The islands experience stable sea conditions with only a small tidal range of approximately $\pm 20 \mathrm{~cm}$, and very little freshwater input during the dry season. Both islands and the waters separating the islands from Honduras mainland are within the $200 \mathrm{~m}$ depth contour (Fig. 1B). Riverine influence is minimal with the mouth of the closest river, Rio El Congrejal, located $30 \mathrm{~km}$ away on mainland Honduras. In 1993, the islands of Cayos Cochinos were designated a marine reserve; the protected area spans $489 \mathrm{~km}^{2}$ and only allows artisanal fishing. Therefore, Utila, which is also a busy tourist destination, most likely suffers from more anthropogenic influence than Cayos Cochinos.

Visual survey methods (belt transects): SCUBA and snorkel underwater visual censuses

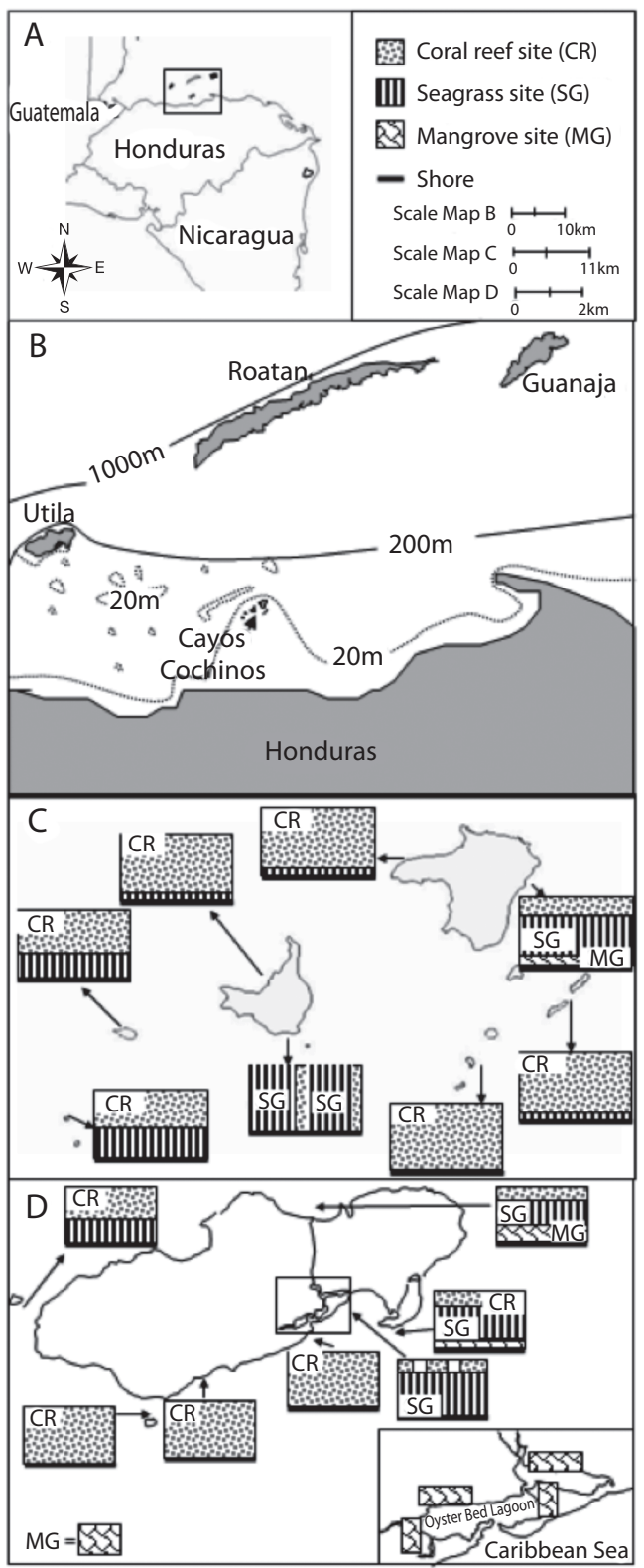

Fig. 1. Study site with (A) reference to location in Central America, (B) bathymetric contours that connect Utila, Cayos Cochinos and mainland Honduras, and $(\mathbf{C}, \mathbf{D})$ the presence and orientation to shore of connected habitat (seagrass, mangroves and/or coral) at each site (type of habitat surveyed depicted by the acronyms SG (seagrass), MG (mangroves) and CR (coral reefs) of Cayos Cochinos and Utila, respectively. 
were performed on seagrass, mangroves and coral reefs during July $2^{\text {nd }}-$ Aug. 27th 2007 and June $22^{\text {nd }}-$ Aug $17^{\text {th }}, 2008$. After deploying a metered tape, surveyors waited five minutes for the fish to resume normal activity before commencing (Tolimieri 1995). All fish, with the exception of small cryptic fish (e.g. gobies, blennies, fish larvae), were visually surveyed. Their sizes were estimated to the nearest $5 \mathrm{~cm}$ fork length (FL), and color variation was noted. Distances between sampling sites were based on findings from previous research (Chapman \& Kramer 2000, Verweij et al. 2007). To ensure that distance between sites were larger than fish home-ranges (and therefore independent), coral reef sites were separated by more than $750 \mathrm{~m}$, mangrove sites were separated by more than $150 \mathrm{~m}$, and seagrass sites more than $100 \mathrm{~m}$.

Fish on coral reefs were surveyed in 11 sites (Utila, $\mathrm{n}=$ five and Cayos Cochinos, $\mathrm{n}=\mathrm{six}$ ). Within each site, eight non-overlapping $50 \mathrm{~m}$ belt transects were laid out randomly (separated by $>10 \mathrm{~m}$ ) on the reef flat parallel to the reef wall (following the depth contour=4$9 \mathrm{~m})$. Fish within $1 \mathrm{~m}$ on each side of the tape and $2.5 \mathrm{~m}$ above the tape were identified and recorded. Fish in seagrass sites $(\mathrm{n}=\mathrm{six})$, which were located more than $20 \mathrm{~m}$ from coral reefs, were surveyed in six $30 \times 2 \mathrm{~m}$ transects per site (depth=1.4-2.1m).

Mangrove sites were either located in Oyster Bed Lagoon on the Southside of Utila ( $\mathrm{n}=$ four) or in fringing mangrove stands immediately adjacent to seagrass and coral reefs ( $n=$ two). In each lagoon site, six $30 \times 2 \mathrm{~m}$ randomly laid transects with at least $10 \mathrm{~m}$ separation were laid abutting grounded prop roots and underneath overhanging roots, while number of transects per site in fringing mangrove stands were limited to five on Utila and three on Cayos Mejor due to fragmentation $($ depth $=0.2$ $1.2 \mathrm{~m}$ ). Mangrove prop roots were dense (linear prop root count per meter $\sim 40$ ) making it impossible to swim between grounded roots. However, tidal inundation extended no more than one meter from the seaward edge of the mangrove forest, making it possible to survey fish within the grounded prop roots from the outside. All fish within primary prop roots and under overhanging roots (transect width of $2 \mathrm{~m}$ ) were identified to the species level.

For data analyses, life stage distinctions (juveniles vs. adults) were based on gonad studies from Munro (1983). Fish species not included in Munro (1983) were defined as juveniles if they were less than $1 / 3^{\text {rd }}$ asymptotic length. Length of mature stages was determined to be approximately $2 / 3^{\text {rd }}$ of the asymptotic length (Jensen 1997). However, length of reproductive maturity decreases with small fish stocks (McGovern et al. 1998, Haugen \& Vollestad 2001, Reznick \& Ghalambor 2005, Sharpe \& Hendry 2009). Due to fishing, a conservative value of $1 / 3^{\text {rd }}$ asymptotic length (based on Humann \& Deloach 2002, Froese \& Pauly 2009) was used. Using this calculation, all values were within $10 \%$ of Munro's (1983) findings. In addition, many juveniles have distinctly different coloration than their adult counterparts (e.g. horizontal stripes on juveniles of the family Haemulidae and typical ontogenetic coloration changes of the families Labridae and Scaridae).

Since surveyed areas differed in size between habitat types (mangrove and seagrass belt transects $=60 \mathrm{~m}^{2}$, coral surveys $=100 \mathrm{~m}^{2}$ ), all abundances were divided by total area of each transect to convert to densities, then expressed as individuals per $100 \mathrm{~m}^{2}$. For analyses, fish density in belt transects were summed within each site in order to avoid pseudoreplication. Shapiro-tests (R 2.10.1 software by Comprehensive R Archive Network) were used to test for normality, and square-root transformations were used when needed. Non-normal data (mean species richness per site) were analyzed using a generalized linear model ( $\mathrm{R}$ 2.10.1) with quasipoisson error distributions. Poisson errors were used because total fish densities were based on count data; quasipoisson errors were used when data was over dispersed (Crawley 2007). For each habitat type, total juvenile and adult densities were calculated by pooling all fish from each survey. Total juvenile densities and individual species' densities were tested with a parametric, one-way ANOVA 
model ( $\mathrm{R}$ 2.10.1), while a generalized linear model (with quasipoisson errors) was used for total adult densities on Cayos Cochinos. Within each habitat, comparisons of juvenile density with adult density were performed with oneway ANOVA models. Comparisons in seagrass habitat required square-root transformed data. Fringing mangrove stands could not be statistically compared, because $\mathrm{n}<$ three.

In order to calculate nursery function (NF) and effective juvenile habitat $(\mathrm{EJH})$, relative contribution and estimated percent surface area of each habitat type were first calculated. Relative contribution was the amount of juveniles in each habitat compared to total juveniles. Percent surface area of each habitat type was estimated using satellite images, underwater surveys, and maps from www.cayoscochinos. org: Cayos (69\% coral reefs, $29 \%$ seagrass and $0.02 \%$ mangroves) and Utila (57\% coral reefs, $33 \%$ seagrass and $0.28 \%$ mangroves).

To determine if community structure differed between habitat types, square-root transformed fish assemblage data was used with Bray-Curtis dissimilarities (sum of absolute differences divided by the total abundance) in an Analysis of Similarity test (ANOSIM; Community Analysis Package (CAP), copyright PISCES 2008). Seagrass, mangrove and coral reef fish density data were separated into juvenile and adult life stages. Community structure comparisons were displayed in a Multidimensional Scaling (MDS) plot with sites bearing similar communities clustering together. Goodness of fit in two dimensions was measured by stress tests (zero represents a perfect fit); acceptable levels are less than 0.2 (Clarke 1993).

\section{RESULTS}

Distribution of fish found on seagrass beds, mangroves and coral reefs: Surveys found 113 species of fish from 32 families in the three habitat types. Fish species richness was significantly higher on coral reefs (mean=49.1, SE=2.4) than seagrass $(12.4,1.2)$ and mangroves $(14.9,0.9)$ (Generalized Linear
Model, $\mathrm{n}=23$, both comparisons $\mathrm{p}<0.001$ ). When fish data were separated by islands, species richness remained significantly different amongst habitats types of both Cayos Cochinos $(p<0.001)$ and Utila $(p<0.001)$. Coral reef surveys were dominated by juveniles of the families Labridae (wrasse) and Scaridae (parrotfish) and adults of the family Pomacentridae (damselfish). Seagrass beds were characterized by the families: Labridae, Scaridae and Haemulidae (grunts). Numerical dominant families found in mangrove surveys included juveniles of Lutjanidae (snapper), Gerreidae (mojarra) and Chaetodontidae (butterflyfish), and resident habitat specialists such as Tetraodontidae (pufferfish) and Rivulidae (killifish). Many fish species used multiple habitat types (Table 1), but densities of commercially important fish varied greatly between sites (Fig. 2).

Nursery function: Many fish species spent their juvenile life stage in seagrass and mangroves. Juvenile and adult densities (individuals per $100 \mathrm{~m}^{2}$ ) were significantly higher on coral reefs relative to seagrass on both Utila (ANOVA, juveniles: $F_{2,9}=2.95, \mathrm{p}=0.038$, adults: $F_{2,9}=10.99, \mathrm{p}<0.001$, Fig. $3 \mathrm{~A}$ ) and Cayos Cochinos (Cayos) (ANOVA, juveniles: $F_{1,7}=2.95, \mathrm{p}<0.001$; Generalized Linear Model, $\mathrm{n}=9, \mathrm{p}<0.001$, Fig. 3B). On Utila, there were significantly more adult fish on coral reefs than in mangroves $(p=0.019)$. Although there appeared to be more juvenile and adult fish in Utila's mangroves than in seagrass, this difference was not significant. Fringing mangrove stands housed the greatest densities of fish; however statistical differences could not be calculated. Therefore, mangrove sites were combined (fringing and lagoon mangroves; Cayos and Utila), resulting in significantly greater densities of fish in mangroves compared to seagrass ANOVA, juveniles: $F_{2,19}=10.88$, $\mathrm{p}=0.04$; Generalized Linear Model, adults: $\mathrm{n}=23, \mathrm{p}=0.02$ ), but fewer fish than in coral reefs (juveniles: $\mathrm{p}=0.03$, adults: $\mathrm{p}=0.005$ ).

Mean densities of adult fish were significantly higher on Utila's coral reefs compared to density of juveniles (ANOVA, $F_{1,8}=8.058$, 


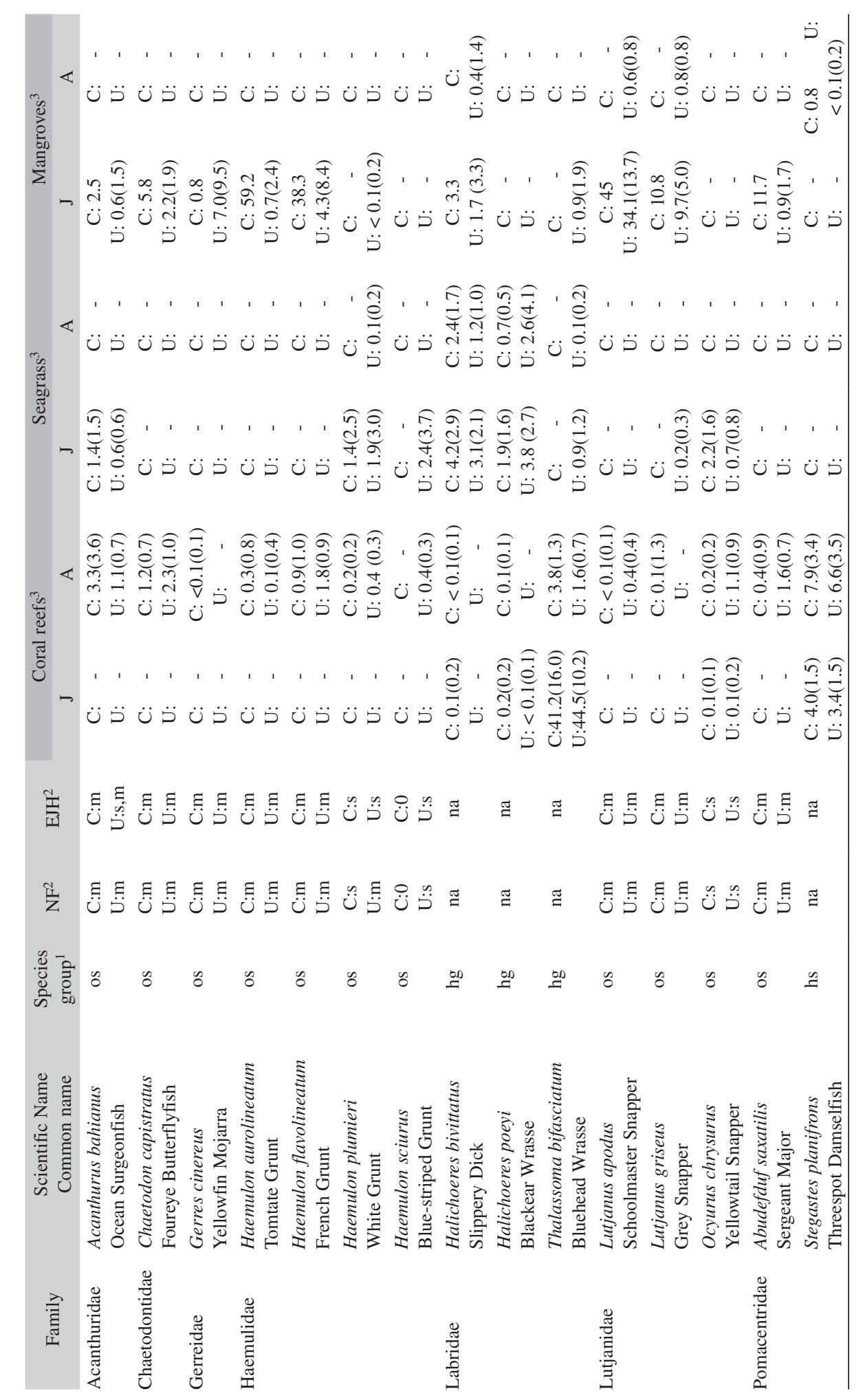




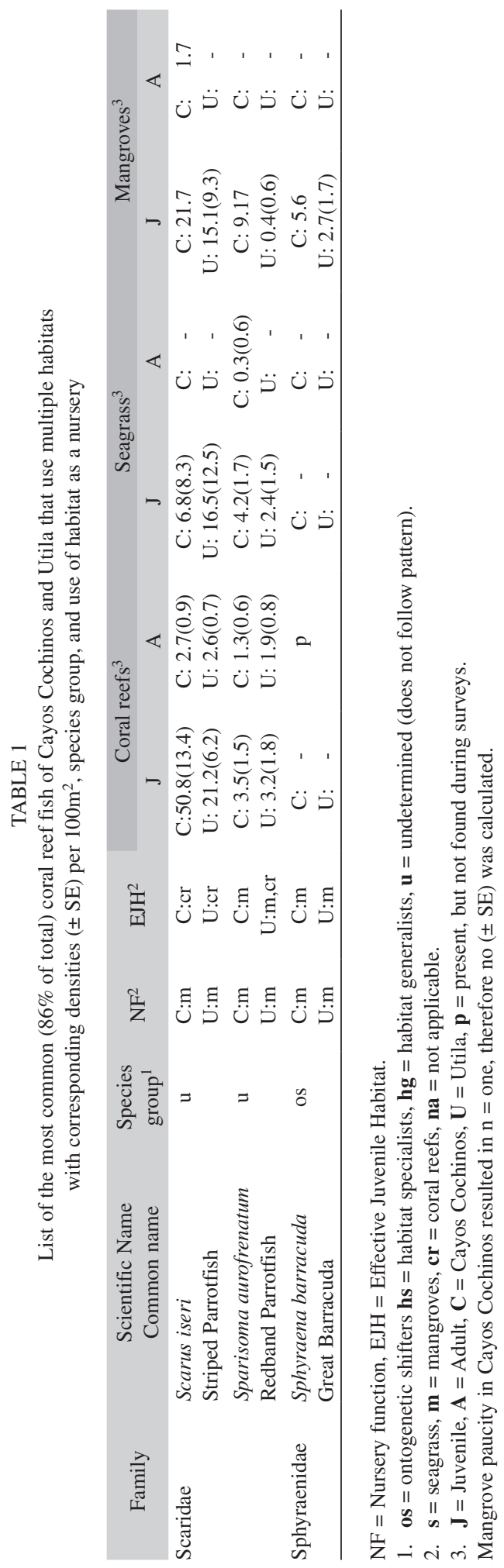

$\mathrm{p}=0.022$ ) contrasting with surveys in seagrass which found more juvenile fish than adults from both islands (Cayos: $F_{1,4}=12.53, \mathrm{p}=0.024$; Utila: $F_{1,4}=12.75, \mathrm{p}=0.023$, Fig. 3). Juvenile densities in mangroves were comparable to adult densities due to resident habitat specialist species which comprised $94 \%$ of adults (seagrass has $<10 \%$ resident habitat specialists).

By separating juvenile and adult stages into families and calculating percent distribution in the habitat types, it was evident that families have distinct ontogenetic partitioning. Chaetodontidae (Butterflyfish) juveniles were restricted to the mangrove habitat, but adults were located mainly on coral reefs (Fig. 4).

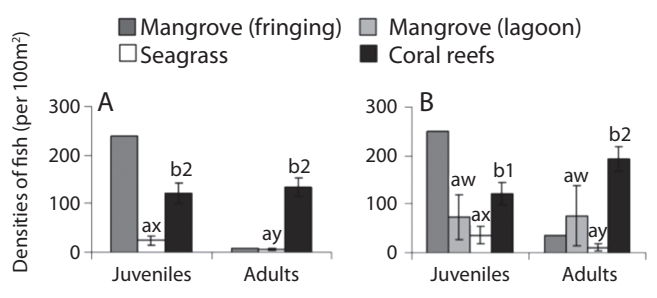

Fig. 3. Mean $\left( \pm\right.$ SE) density (individuals per $\left.100 \mathrm{~m}^{2}\right)$ of total fish per habitat in (A) Cayos Cochinos and (B) Utila. Difference between habitat type denoted by "abc". Differences between lifestages of fish within each habtitat is denoted by "vw", "xy" and "1, 2". Fringing mangrove stands could not be statistically compared, because $n<$ three.

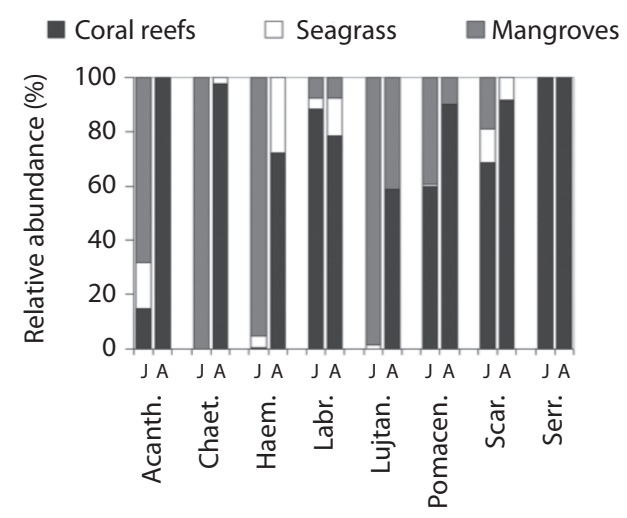

Fig. 4. Comparison of habitat partitioning between juveniles ( $\mathrm{J}$ ) and adults (A) of the eight most common surveyed fish families. Acanth. - Acanthuridae; Chaet. Chaetodontidae; Haem. - Haemulidae; Labr. - Labridae; Lutjan. - Lutjanidae; Pomacen. - Pomacentridae; Scar. Scaridae; Serr. - Serranidae. 

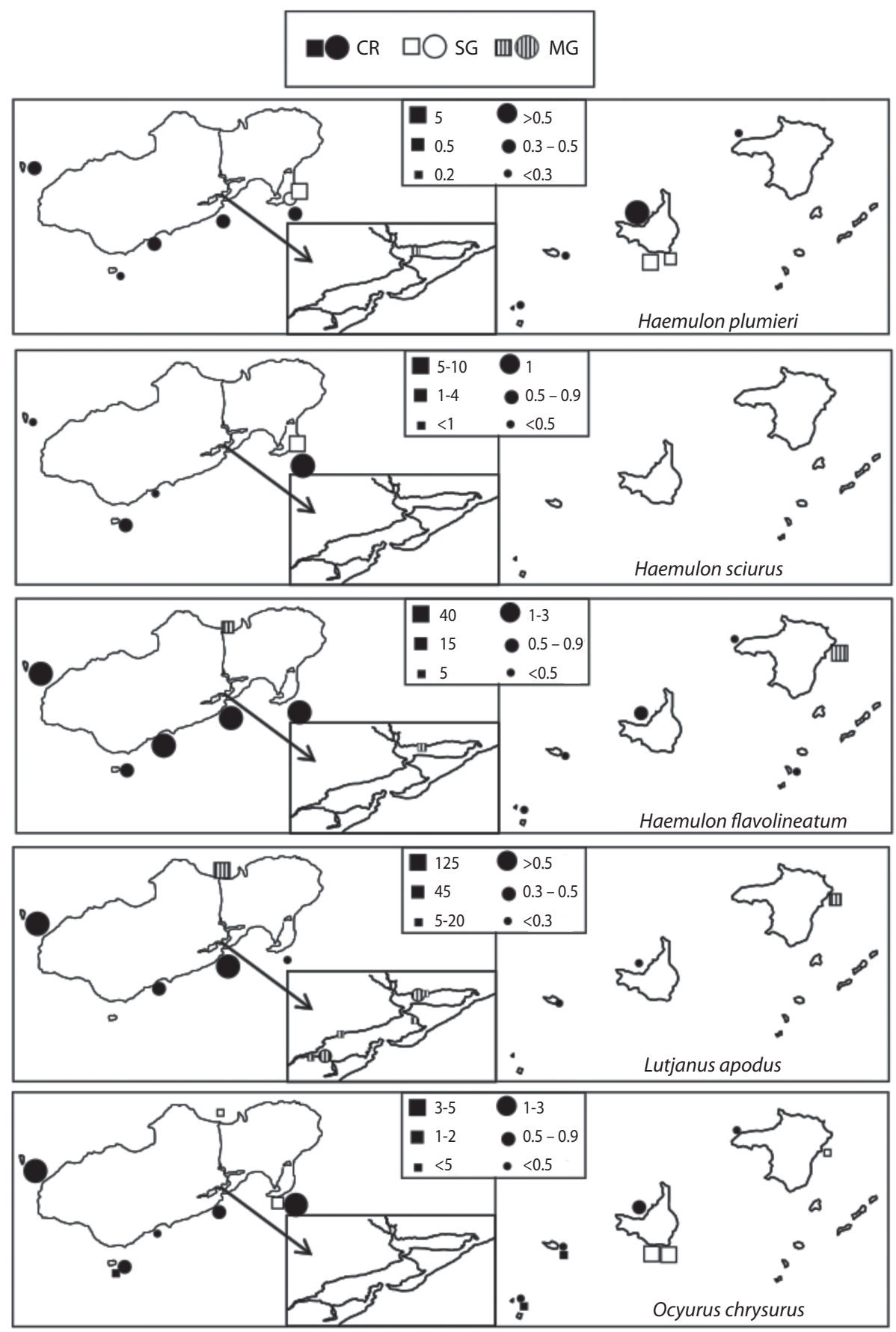

Fig. 2. Distribution and density (individuals per $100 \mathrm{~m}^{2}$ ) of commercially important ontogenetic shifters on Utila (left) and Cayos Cochinos (right). Squares represent fish juveniles, while circles represent fish adults in the following habitats: coral reefs (CR), seagrass (SG) and mangroves (MG). 
Haemulidae and Lutjanidae juveniles were found in seagrass but in relatively few numbers compared to mangroves, while both had higher percentages on coral reefs as adults. Although Acanthuridae (Surgeonfish) and Pomacentridae adults were found mainly on coral reefs, their juveniles were found in multiple habitat types. In contrast, all life stages from the families Scaridae, Labridae and Serranidae (Groupers) occurred primarily on coral reefs. Haemulidae and Lutjanidae size-frequency distributions suggest fork length sizes at which fish migrate to coral reefs (Fig. 5). Lutjanus apodus (Walbaum, 1792) and H. flavolineatum (Desmarest, 1823) migrate directly from mangroves to coral reefs, while Haemulon plumieri (Lacepède, 1801) and H. sciurus (Shaw, 1803) use seagrass as an intermediate habitat during ontogenetic migration. Juveniles of the Yellowtail Snapper Ocyurus chrysurus (Bloch, 1791) were only found in seagrass sites (Table 1, Fig. 5).

Families whose juveniles were found in more than one habitat type often included some species that occurred in only one habitat and others occurring in two or three. Importance, measured by nursery function (NF) and effective juvenile habitat (EJH), of seagrass and mangrove nurseries varied greatly according to species. For example, the striped parrotfish Scarus iseri (Bloch, 1789) was the most common in relative abundance, comprising $12 \%$ of total individuals surveyed in the present study. $S$. iseri juveniles were not only present on coral reefs, but also in mangroves and seagrass (Table 1). All S. iseri adults were found on coral reefs, and it is unknown if juveniles found in mangroves and seagrass undergo ontogenetic migration or move freely between multiple habitats. Although mangroves contributed the most $S$. iseri juveniles per area (NF), coral reefs were an effective juvenile habitat due to great densities of juveniles in this large habitat. In contrast, the corallivorous Four-eye Butterflyfish Chaetodon capistratus (Linnaeus, 1758) and snapper juveniles Lutjanus griseus (Linnaeus, 1758) and L. apodus were found primarily in mangroves (considered both NF and EJH) while in the juvenile life stage (Table 1). Very few adult-sized fish $(<10 \%$ of total) from the family Lutjanidae were found in the mangroves,
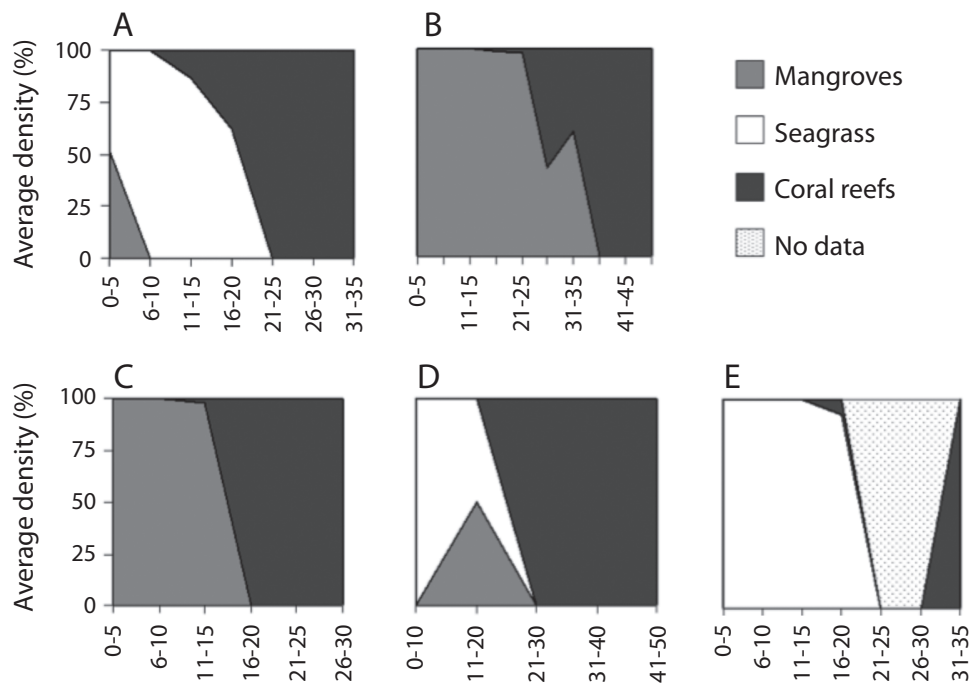

Fig. 5. Size-frequency distribution (\% density) of commercially important ontogenetic shifters in different habitats according to size class (cm). (A) Haemulon plumieri, (B) Lutjanus apodus, (C) H. flavolineatum, (D) H. sciurus, (E) Ocyurus chrysurus. 
and these adults were relatively small $(<25 \%$ larger than $25 \mathrm{~cm}$ with $1 \%$ larger than $35 \mathrm{~cm}$ ). Acanthurid juveniles were observed in all three habitat types, primarily because Acanthurus bahianus juveniles (Castelnau, 1855) were found in seagrass (EJH on Utila) and mangroves (both EJH and NF), while both $A$. coeruleus (Bloch \& Schneider, 1801) juveniles (Cayos densities: mean $=0.3, \mathrm{SE}=0.3$; Utila densities: 0.5, 0.4) and adults (Cayos densities: 2.7; 3.0; Utila densities: 7.2, 7.8) resided on coral reefs. Like A. coeruleus, many coral reef fish species in this survey were found to be reef specialists i.e. they did not exploit nursery grounds away from reefs; all their juveniles were found only on coral reefs. The three most common coral reef habitat specialists include Bicolor Damselfish Stegastes partitus (Poey, 1868; combined juvenile and adult densities, Cayos: mean=25.9, $\mathrm{SE}=8.0$; Utila: $30.8,7.6$ ), Blue Chromis Chromis cyanea (Poey, 1860; combined juvenile and adult densities, Cayos: 6.7, 3.7; Utila: 38.1, 15.7), and Yellowhead Wrasse Halichoeres garnoti (Valenciennes, 1839; combined juvenile and adult densities, Cayos: 12.7, 3.1; Utila: 20.0, 4.7).
Fish community differences between habitat types: On the juvenile life stage MDS ordination plot, three major clusters could be distinguished corresponding to seagrass, mangrove and coral reef habitats, and there was a significant difference amongst all three fish assemblage clusters (Analysis of Similarity, $\mathrm{R}=0.93$, $\mathrm{p}<0.001$, Fig. 6A). Adult fish assemblages showed a similar pattern (overall groups were significantly different, $\mathrm{R}=0.88, \mathrm{p}<0.001$ ), except fish assemblages in fringing mangrove stands were clustered closer to seagrass than those in mangrove lagoons (Fig. 6B).

\section{DISCUSSION}

Fish distribution: The present study showed that the fish communities in all three habitats were distinctly different. Seagrass, mangroves and coral reefs contained high numbers of fish species paralleling numbers of species found in Aguilar-Perera \& Appeldoorn's Puerto Rican study (102 species in 2008) and Chittaro et al. Bahamas, Mexico, and Belize study (82 species in 2005). We found very few Lutjanus apodus juveniles outside of

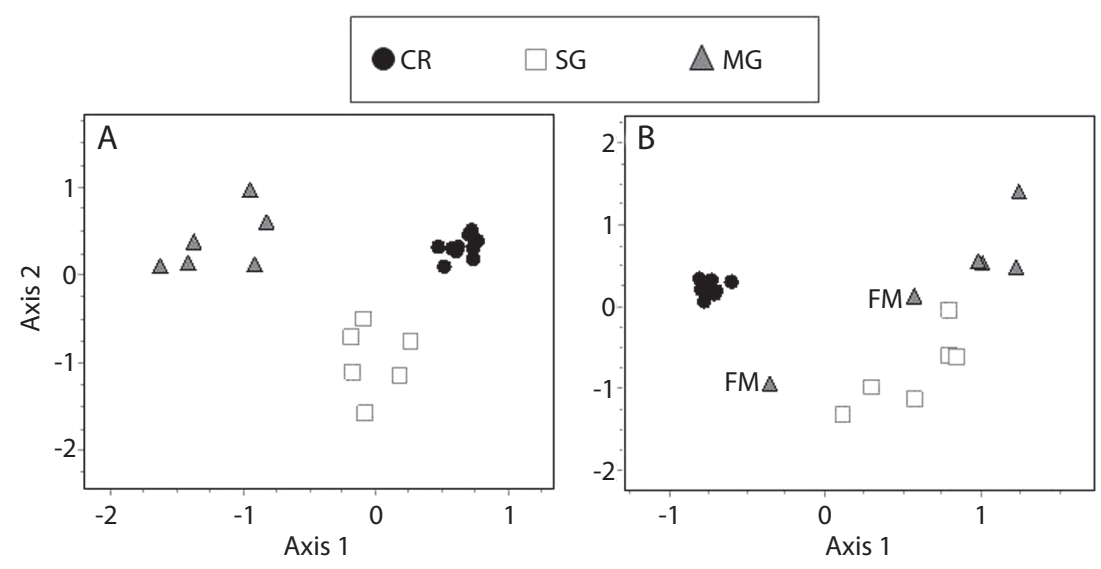

Fig. 6. Multi-dimensional scaling ordination plot (Bray-Curtis dissimilarity coefficient) of fish assemblages found on coral reefs (CR), seagrass (SG) or mangroves (MG). Each point represents fish assemblage at one site (summed replicates); (A) Juvenile fish assemblages, 2D stress $=0.1069$ and (B) Adult fish assemblages, 2D stress=0.0317. FM: Fringing mangrove stands (Northside of Utila and Cayos Cochinos). 
mangroves, which correspond with previous studies suggesting that mangroves provide an important nursery habitat for these juveniles (Nagelkerken et al. 2000a, Mumby et al. 2004, Chittaro et al. 2005, Aguilar-Perera \& Appeldoorn 2007). Honduran ichthyofaunal composition was comparable with findings from many Caribbean studies; however there were a few notable differences particularly at the species level. Surveys from Honduras (present study), the British Virgin Islands (Gratwicke $e t$ al. 2006) and the coral reefs of Cayos Cochinos, Honduras (Clifton \& Clifton 1998) shared domination by the Striped Parrotfish Scarus iseri. However, Chittaro et al. (2005) study in Belize, Mexico, and Bahamas found the Blackear Wrasse Halichoeres poeyi (Steindachner, 1867) was the most abundant individual found during surveys, which differs from the present study's low densities. In addition to S. iseri, Bluehead Wrasse Thalassoma bifasciatum and Bicolored Damselfish Stegastes partitus dominated the coral reefs of Honduras, Puerto Rico (Aguilar-Perera \& Appeldoorn 2008) and Curacao (Nagelkerken et al. 2000a). Most nonestuarine studies found Lutjanidae, Scaridae and Haemulidae as the most abundant families in seagrass and mangroves, although dominant species within these families varied between studies (Nagelkerken et al. 2000a, AguilarPerera \& Appeldoorn 2007, Dorenbosch et al. 2007). For example, Haemulon flavolineatum was the most abundant fish species in both seagrass and mangrove habitats of Curacao (Nagelkerken et al. 2000a). In contrast, the present study in Honduras found that Lutjanus apodus dominated mangrove surveys, and Haemulon flavolineatum was not present in seagrass. These differences in fish distributions amongst studies emphasize the importance of determining nursery function at a site level.

Nursery function: The present study in Honduras, like other Caribbean studies, found that mangroves and seagrass habitats were characterized by juvenile fish occupancy (Sedberry \& Carter 1993, Nagelkerken et al. 2000a). This pattern illustrates the role of these two habitats as fish nursery grounds. In fact, out of 48 juvenile species surveyed, $52 \%$ were found on habitat types other than coral reefs, suggesting that these alternative habitats are very important. It is significant to note that use of habitat does not imply nursery value. For example, although Lutjanus griseus juveniles and many Labridae juveniles were found in seagrass habitats, these did not have a nursery ground use by these individuals. L. griseus densities were too low to result in NF and EJH, while the Labridae individuals were habitat generalists, using multiple habitat types at all life stages. Within families, closely related species sometimes used different juvenile habitat types, and therefore differed in which habitats had nursery value (NF and EJH). Although all Chaetodontidae juveniles used mangroves as nurseries, juvenile habitat association of species such as from the Scaridae family differed between species. In particular, Sparisoma aurofrenatum juveniles (Redband Parrotfish) were found in highest numbers in seagrass beds, while Scarus iseri (Striped Parrotfish) were found in all three habitat types with highest densities on coral reefs. In contrast to findings in Honduras and one Belize study (Chittaro et al. 2005), studies in Curacao (Nagelkerken et al. 2002) and another in Belize (Mumby et al. 2004) found the majority of S. iseri in non-coral habitats. These niche differentiations emphasize the need to evaluate fish distribution amongst habitats to the species level, in addition to the site level. In fact, use of nursery habitat varied on a small spatial scale within the geographic scope of the present study. For example, although seagrass contributed a large percentage to total habitat, only one site $\left(16^{\circ} 05^{\prime} 15^{\prime} " \mathrm{~N}-86^{\circ} 53^{\prime} 38^{\prime \prime} \mathrm{W}\right)$ contained fish densities greater than 100 individuals per $100 \mathrm{~m}^{2}$. This site contained more than three times the fish densities than other seagrass sites. The site was part of a small fringing mangrove-seagrass-coral reef continuum as was two out of the five other seagrass sites, therefore seascape is most likely not the explanation behind these differences. Faunce \& Serafy (2006) review of mangrove studies has cautioned against generalizing nursery value of 
mangroves on a spatial scale $>500 \mathrm{~m}$, however findings from the present study in Honduras, Chittaro et al. (2005), and Dorenbosch et al. (2007) Caribbean studies suggest that nursery value be determined at a site level.

Habitat connectivity: Seascape ecology implies that habitats do not 'function in isolation'; instead, the spatial arrangement of seagrass, mangrove and coral reef habitats in relation to each other may influence fish distribution (Dorenbosch et al. 2007, Pittman et al. 2007). Habitat configuration dictates habitat connectivity, and fish move between habitats via the larval recruitment process (Roberts et al. 1997, Paris et al. 2007), daily migration (Nagelkerken et al. 2000b, Nagelkerken et al. (2008) and ontogenetic migration (Nakamura et al. 2008, Verweij et al. 2008). In the present study, adult fish assemblages found in fringing mangrove stands on Cayos Cochinos and Utila's Northside were similar to seagrass beds, and had higher species richness and more juveniles from the grunt and parrotfish families than found in mangroves in Oyster Bed Lagoon. Because Cayos Cochinos had only a small mangrove stand and the majority of mangroves on Utila were located in geographically semi-isolated lagoons, most nursery species preferred either mangroves or seagrass, and most species that were found in both habitats were all found in fringing mangrove stands adjacent to seagrass (themselves adjacent to the coral reefs). Daily migration out of mangroves is much more feasible when adjacent habitats (e.g. seagrass) are available than when mangroves are isolated. Previous fish studies of mangroves in Curacao found most nursery species were residing in both seagrass and mangroves (Nagelkerken et al. 2000a, 2002). Like the fringing mangrove stands of the present study, Nagelkerken's studies were performed in sites with highly connected fringing mangroves. Both fish communities had to migrate only a short distance in the seagrassmangrove continuum, and likely used both habitats. Differences between connected versus isolated mangroves were also found in a study performed in Florida where greater abundances of Haemulidae were found in mangroves with adjacent seagrass than in isolated mangroves (Pittman 2007). Likewise, Dorenbosch et al. (2007) found significantly more adult species on mangroves near reefs compared to semi-isolated mangroves. Thus, results agree with previous research (Gratwicke et al. 2006, Dorenbosch et al. 2007), which have found spatial patterns and density distributions of fish depend on complexity of connectivity with more connected habitats housing higher abundances and greater species richness.

Although visual surveys found resident habitat specialists in non-coral reef habitat (e.g. mangrove specialist Sphoeroides testudineus, Checkered Pufferfish), most fish juveniles found in alternate habitat types were surveyed on coral reefs in the adult life stage. Fish settlement often occurs in a habitat different from that used by adults (Cocheret de la Morinière et al. 2004, Adams \& Ebersole 2004). Size frequency distribution of the Haemulidae and Lutjanidae families in the present study implies habitat connectivity through ontogenetic migration. Sizes at which these fish families were first found on Honduran coral reefs parallels those of Cocheret de la Morinière's et al. (2003) Curacao study (>10cm FL). Cocheret de la Morinière's et al. (2003) study also found that Haemulidae undergo a change in diet and gonadal maturation just prior to migration from nursery habitats, while Lutjanidae migrate to coral reefs before sexual maturation (diet plays larger role). Furthermore, two Australian species from the family Lutjanidae were found to be reproductively immature when located in mangrove estuaries despite their large sizes (Sheaves 1995). Therefore, it must be noted that the large Lutjanidae classified as adults (according to Munro 1983) in the present study's mangrove habitat may in fact be immature. Further studies are needed to investigate whether findings regarding Australian Lutjanidae can be applied in the Caribbean.

As mentioned above, most large, adult fish were observed in coral reefs. However, there was a distinct paucity $(<1 \%)$ of large fish over $45 \mathrm{~cm}$ FL in this Honduran fish survey. In 
particular, commercially important groupers, which are benthic coral reef fish, were found in very low densities (mean density of groupers $<1.0$ individual per $100 \mathrm{~m}^{2}$ ). The most prevalent grouper found in the surveys were the Graysby Grouper, Cephalopholis cruentatus (Lacepède, 1802), which is one of the smallest species belonging to the grouper family. Other studies in the Caribbean have also reported low numbers of groupers, attributing population decline to overfishing and reef degradation (Rogers \& Beets 2001, Aguilar-Perera et al. 2009). Although groupers (coral reef specialists) are not directly affected by the presence of nursery habitats, they may be indirectly influenced through food chain dynamics.

Previous studies have shown that juvenile fish communities, in particular those located in nursery habitats, may shape adult fish communities on coral reefs (Mumby et al. 2004, Verweij et al. 2008). Results from Harm et al. (2008) indicated the presence of mangroves in Honduras enhanced densities of seven species of coral reef fish adults. Generally, fish distributions in Honduras's seagrass, mangrove and coral reef habitats were similar to previous studies in the Caribbean and MBRS. However, nursery value appeared to differ amongst species and sites, revealing the importance of performing local surveys before determining which locations and combination of habitats should be prioritized for conservation action.

\section{ACKNOWLEDGMENTS}

We thank St. Catherines College (Oxford) and Operation Wallacea (and their partners in Honduras) for their financial contributions. We would also like to thank Clive Hambler, Peter Henderson, Mark Jaxion, Owen Harris, Emily Kearns, and Mikki Haig for their assistance with study design, aid with statistics, and help in the field.

\section{RESUMEN}

Muchos peces de arrecifes de coral estan sometidos a la fragmentación del habitat a lo largo de su vida. Estos patrones son evidentes en el Caribe donde la investigación se llevó a cabo, principalmente en la región este. La motivación para la realización de este trabajo fue la escasez de datos sobre la distribución de peces de arrecife de Honduras en tres tipos de hábitat (pastos marinos, manglares y arrecifes de coral), por lo que se realizaron censos de peces en las islas de Utila y Cayos Cochinos en la costa de Honduras (parte del Sistema Arrecifal Mesoamericano). Del 2 de Julio al 27 de agosto 2007 y del 22 de junio al 17 agosto 2008, se realizaron censos visuales (buceo y snorkel) en transectos de diferente área: 11 en arrecifes de coral, 6 en praderas de pastos marinos y 6 en manglares. La densidad de jóvenes y el área total de la superficie del hábitat se utilizaron para calcular el valor de la zona de crianza de pastos marinos y manglares. Un total de 113 especies de peces de 32 familias fueron encontrados durante los censos. Análisis Multi-dimensionales reveló distintos grupos de comunidades de peces en cada tipo de hábitat por la separación de los peces asociados a los lechos de pastos marinos, manglares y arrecifes de coral. Los arrecifes de coral presentaron el mayor promedio de riqueza de especies de peces y fueron dominados por peces adultos, mientras que los jóvenes se caracterizaron por encontrarse en praderas de pastos marinos y zonas de manglares. El uso del hábitat difiere ampliamente a nivel de especies de peces. Scarus iseri (loro rayado), el pez más abundante en este estudio, se encontró en los tres tipos de hábitats, mientras que Lutjanus apodus, los jóvenes, se encontraron principalmente en los manglares antes de emigrar a los arrecifes de coral. Muchas especies utilizan las praderas marinas y los manglares como criaderos, sin embargo, el valor de criadero no puede ser generalizado a nivel familiar. Además, para algunas especies de peces, el valor de criadero varió entre las islas y los sitios. Nuestros resultados sugieren que la conectividad de los pastos marinos, manglares y arrecifes de coral a nivel de especies y sitios, debe ser tomado en cuenta para la aplicación de políticas y prácticas de conservación.

Palabras clave: peces de arrecifes de coral, conectividad, sitios de criaza, pastos marinos, manglares, Honduras.

\section{REFERENCES}

Adams, A.J. \& J.P. Ebersole. 2004. Processes influencing recruitment inferred from distributions of coral reef fishes. Bull. Mar. Sci. 75: 153-174.

Adams, A.J., C.P. Dahlgren, G.T. Kellison, M.S. Kendall, C.A. Layman, J.A. Ley, I. Nagelkerken \& J.E. Serafy. 2006. Nursery function of tropical back-reef systems. Mar. Ecol. Progr. 318: 287-301.

Aguilar-Perera, A. \& R.S. Appeldoorn. 2007. Variation in juvenile fish density along the mangrove-seagrasscoral reef continuum in SW Puerto Rico. Mar. Ecol. Progr. 348: 139-148. 
Aguilar-Perera, A. \& R.S. Appeldoorn. 2008. Spatial distribution of marine fishes along a cross-shelf gradient containing a continuum of mangrove-seagrass-coral reefs off southwestern Puerto Rico. Estuar. Coast. Shelf. Sci. 76: 378-394.

Aguilar-Perera, A., C. Gonzalez-Salas, A. Tuz-Sulub \& H. Villegas-Hernandez. 2009. Fishery of the Goliath grouper, Epinephelus itajara (Teleostei: Epinephelidae) based on local ecological knowledge and fishery records in Yucatan, Mexico. Rev. Biol. Trop. 57: 557-566.

Almany, G.R. 2004. Does increased habitat complexity reduce predation and competition in coral reef fish assemblages? Oikos 106: 275-284.

Anonymous (Food and Agriculture Organization of the United Nations). 2007. The world's mangroves 1980-2005. FAO Forestry Paper 153. FAO, Rome (Downloaded: 01 May, 2010, http://www.fao.org/ docrep/010/a1427e/a1427e00.htm).

Beck, M.W., K.L. Heck, K.W. Able, D.L. Childers, D.B. Eggleston, B.M. Gillanders, B. Halpern, C.G. Hays, K. Hoshino, T.J. Minello, R.J. Orth, P.F. Sheridan \& M.P. Weinstein. 2001. The identification, conservation, and management of estuarine and marine nurseries for fish and invertebrates. Bioscience 51: 633-641.

Chapman, M.R. \& D.L. Kramer. 2000. Movements of fishes within and among fringing coral reefs in Barbados. Environ. Biol. Fish. 57: 11-24.

Clarke, K.R. 1993. Nonparametric multivariate analyses of changes in community structure. Aust. J. Ecol. 18: $117-143$.

Clifton, K.E. \& L.M. Clifton. 1998. A survey of fishes from various coral reef habitats within the Cayos Cochinos Marine Reserve, Honduras. Rev. Biol. Trop. 46: 109-124.

Chittaro, P.M., P. Usseglio \& P. Sale. 2005. Variation in fish density, assemblage composition and relative rates of predation among mangrove, seagrass and coral reef habitats. Environ. Biol. Fish. 72: 175-187.

Cocheret de la Morinière, E., B.J.A. Pollux, I. Nagelkerken \& G. van der Velde. 2003. Diet shifts of Caribbean grunts (Haemulidae) and snappers (Lutjanidae) and the relation with nursery-to-coral reef migrations. Est. Coast. Shelf Sci. 57: 1079-1089.

Cocheret de la Morinière, E., I. Nagelkerken, H. van der Meij \& G. van der Velde. 2004. What attracts juvenile coral reef fish to mangroves: habitat complexity or shade? Mar. Biol. 144: 139-145.
Crawley, M.J. 2007. The R Book. John Wiley and Sons, West Sussex, United Kingdom.

Dahlgren, C.P., G.T. Kellison, A.J. Adams, B.M. Gillanders, M.S. Kendall, C.A. Layman, J.A. Ley, I. Nagelkerken \& J.E. Serafy. 2006. Marine nurseries and effective juvenile habitats: concepts and applications. Mar. Ecol. Progr. 312: 291-295.

Dorenbosch, M., W. Verberk, I. Nagelkerken \& G. van der Velde. 2007. Influence of habitat configuration on connectivity between fish assemblages of Caribbean seagrass beds, mangroves and coral reefs. Mar. Ecol. Progr. 334: 103-116.

Faunce, C.H. \& J.E. Serafy. 2006. Mangroves as fish habitat: 50 years of field studies. Mar. Ecol. Progr. 318: $1-18$.

Froese, F. \& D. Pauly. 2009. FishBase. (Downloaded: 01 May, 2010, www.fishbase.org).

Gratwicke, B., C. Petrovic \& M.R. Speight. 2006. Fish distribution and ontogenetic habitat preferences in non-estuarine lagoons and adjacent reefs. Environ. Biol. Fish. 76: 191-210.

Greenfield, D.W. \& R.K. Johnson. 1990a. Community structure of western Caribbean blennioid fishes. Copeia 433-448.

Greenfield, D.W. \& R.K. Johnson. 1990b. Heterogeneity in habitat choice in cardinalfish community structure. Copeia 1107-1114.

Halpern, B.S., S. Walbridge, K.A. Selkoe, C.V. Kappel, F. Micheli, C. D’Agrosa, J.F. Bruno, K.S. Casey, C. Ebert, H.E. Fox, R. Fujita, D. Heinemann, H.S. Lenihan, E.M.P. Madin, M.T. Perry, E.R. Selig, M. Spalding, R. Steneck \& R. Watson. 2008. A global map of human impact on marine ecosystems. Science 319: 948-952.

Harm, J., E. Kearns \& M.R. Speight. 2008. Differences in coral-reef fish assemblages between mangrove-rich and mangrove-poor islands of Honduras islands. Proc. 11th. Intl. Coral. Reef. Symp. 1: 302-306.

Haugen, T.O. \& L.A. Vøllestad. 2001. A century of lifehistory evolution in grayling. Genetica 112: 475-491.

Humann, P. \& N. Deloach. 2002. Reef fish identification: Florida, Caribbean, Bahamas. New World, Jacksonville, Florida, USA.

Jensen, A.L. 1997. Origin of the relation between K and L-inf and synthesis of relations among life history parameters. Can. J. Fish. Aquat. Sci. 54: 987-989. 
Layman, C.A., D.A. Arrington, R.B. Langerhans \& B.R. Silliman. 2004. Degree of fragmentation affects fish assemblage structure in Andros Island (Bahamas) estuaries. Caribb. J. Sci. 40:232-244.

Laegdsgaard, P. \& C. Johnson. 2001. Why do juvenile fish utilize mangrove habitats? J. Exp. Mar. Biol. Ecol. 257: 229-253.

McGovern, J.C., D.W. Wyanski, O. Pashuk, C.S. Manooch III \& G.R. Sedberry. 1998. Changes in the sex ratio and size at maturity of gag, Mycteroperca microlepis, from the Atlantic coast of the southeastern United States during 1976-1995. Fish. Bull. 96: 797-807.

Mumby, P.J., A.J. Edwards, J.E. Arlas-Gonzalez, K.C. Lindeman, P.G. Blackwell, A. Gall, M.I. Gorczynska, A.R. Harborne, C.L. Pescod, H. Renken, C.C.C. Wabnitz \& G. Llewellyn. 2004. Mangroves enhance the biomass of coral reef fish communities in the Caribbean. Nature 427: 533-536.

Munro, J.L. 1983. Caribbean coral reef fishery resources. The WorldFish Center, Manila, Philippines.

Nagelkerken, I., M. Dorenbosch, W. Verberk, E. Cocheret de la Morinière \& G. van der Velde. 2000a. Importance of shallow-water biotopes of a Caribbean bay for juvenile coral reef fishes: patterns in biotope association, community structure and spatial distribution. Mar. Ecol. Progr. 202: 175-192.

Nagelkerken, I., M. Dorenbosch, E. Cocheret de la Morinière, W.C.E.P. Verberk \& G. van der Velde. 2000b. Day-night shifts of fishes between shallow-water biotopes of a Caribbean bay, with emphasis on the nocturnal feeding of Haemulidae and Lutjanidae. Mar. Ecol. Progr. 194: 55-64.

Nagelkerken, I., C.M. Roberts, G. van der Velde, M. Dorenbosch, M.C. van Riel, E. Cocheret de la Morinière \& P.H. Nienhuis. 2002. How important are mangroves and seagrass beds for coral reef fish? The nursery hypothesis tested on an island scale. Mar. Ecol. Progr. 244: 299-305.

Nagelkerken, I., J. Bothwell, R.S. Nemeth, J.M. Pitt \& G. van der Velde. 2008. Interlinkage between Caribbean coral reefs and seagrass beds through feeding migrations by grunts (Haemulidae) depends on habitat accessibility. Mar. Ecol. Progr. 368: 155-164.

Nakamura, Y., M. Horinouchi, T. Shibuno, Y. Tanaka, T. Miyajima, I. Koike, H. Kurokura \& M. Sano. 2008. Evidence of ontogenetic migration from mangroves to coral reefs by black-tail snapper Lutjanus fulvus: stable isotope approach. Mar. Ecol. Progr. 355: 257-266.

Paris, C.B., L.M. Chérubin \& R.K. Cowen. 2007. Surfing, spinning, or diving from reef to reef: effects on population connectivity. Mar. Ecol. Progr. 347: 285-300.

Pittman, S.J., C.A. McAlpine \& K.M. Pittman. 2004. Linking fish and prawns to their environment: a hierarchical landscape approach. Mar. Ecol. Progr. 283: 233-254.

Pittman, S.J., C. Caldow, S.D. Hile \& M.E. Monaco. 2007. Using seascape types to explain the spatial patterns of fish in the mangroves of SW Puerto Rico. Mar. Ecol. Progr. 348: 273-284.

Reznick, D.N. \& C.K. Ghalambor. 2005. Can commercial fishing cause evolution? Answers from guppies (Poecilia reticulata). Can. J. Fish. Aquat. Sci. 62: 791-801.

Roberts, C.M. 1997. Connectivity and management of Caribbean coral reefs. Science 278: 1454-1457.

Rogers, C.S. \& J. Beets. 2001. Degradation of marine ecosystems and decline of fishery resources in marine protected areas in the US Virgin Islands. Environ. Cons. 28: 312-322.

Sedberry, G.R. \& J. Carter. 1993. The fish community of a shallow tropical lagoon in Belize, Central America. Estuaries 16: 198-215.

Sharpe, D.M.T. \& A.P. Hendry. 2009. Life history change in commercially exploited fish stocks: an analysis of trends across studies. Evol. Appl. 2: 260-275.

Sheaves, M. 1995. Large lutjanid and serranid fishes in tropical estuaries: Are they adults or juveniles? Mar. Ecol. Progr. 129: 31-40.

Tolimieri, N. 1995. Effects of microhabitat characteristics on the settlement and recruitment of a coral reef fish at two spatial scales. Oecologia 102: 52-63.

Verweij, M.C., I. Nagelkerken, S.L.J. Wartenbergh, I.R. Pen \& G. van der Velde. 2006. Caribbean mangroves and seagrass beds as daytime feeding habitats for juvenile French grunts, Haemulon flavolineatum. Mar. Biol. 149: 1291-1299.

Verweij, M.C., I. Nagelkerken, K.E.M. Hol, A. van den Beld \& G. van der Velde. 2007. Space use of Lutjanus 
apodus including movement between a putative nursery and a coral reef. Bull. Mar. Sci. 81: 127-138.

Verweij, M.C., I. Nagelkerken, I. Hans, S.M. Ruseler \& P.R.D. Mason. 2008. Seagrass nurseries contribute to coral reef fish populations. Limnol. Oceanogr. 53: 1540-1547.

Waycott, M., C.M. Duarte, T.J.B Carruthers, R.J. Orth, W.C. Dennison, S. Olyarnik, A. Calladine, J.W
Fourqurean, K.L. Heck, A.R. Hughes, G.A. Kendrick, W.J. Kenworthy, F.T. Short \& S.L. Williams. 2009. Accelerating loss of seagrasses across the globe threatens coastal ecosystems. Proc. Natl. Acad. Sci. USA. 106: 12377-12381.

Wilkinson, C. 2008. Status of coral reefs of the world: 2008. Global Coral Reef Monitoring Network/Australian Institute of Marine Science (Downloaded: 01 May, 2010, www.gcrmn.org). 